\title{
Diabetes-induced alterations in calcium homeostasis in sensory neurones of streptozotocin-diabetic rats are restricted to lumbar ganglia and are prevented by neurotrophin-3
}

\author{
T.-J.Huang, N. M. Sayers, P. Fernyhough, A. Verkhratsky \\ ${ }^{1}$ School of Biological Sciences, University of Manchester, Manchester, UK
}

\begin{abstract}
Aims/hypothesis. In diabetic sensory polyneuropathy the earliest and most severe pathophysiology occurs in neurones with the longest axons. The aim of this study was to characterise a diabetes-induced neurodegenerative marker that was selective for sensory neurones with the longest axons. We studied alterations in calcium homeostasis since this occurs in other neurodegenerative diseases.

Methods. Sensory neurones were cultured from control and streptozotocin-diabetic rats, treated with or without human recombinant neurotrophin-3 (hrNT3), and neurones from L4-L6 dorsal root ganglia (DRG) which exhibit the longest axons in vivo were compared with those from C5-L3 DRG. Fluorescent video-imaging was used to measure cytoplasmic calcium dynamics.

Results. Streptozotocin diabetes of 8 to 14 weeks, induced an increase in resting internal $\mathrm{Ca}^{2+}$ concentration $\left(\left[\mathrm{Ca}^{2+}\right]_{\mathrm{i}}\right)$, from $67 \pm 7 \mathrm{nmol} / 1$ in small neurones and $79 \pm 9 \mathrm{nmol} / \mathrm{l}$ in big neurones obtained from control animals to $214 \pm 19 \mathrm{nmol} / \mathrm{l}$ in small neurones and $273 \pm 30 \mathrm{nmol} / \mathrm{l}$ in big neurones after 14 weeks of dia-
\end{abstract}

betes $(p<0.05)$ in L4-L6 DRG cultures. Neurones from C5-L3 ganglia and non-neuronal cells were not affected. Treatment of 14-week streptozotocin-diabetic rats with subcutaneous injection of $5 \mathrm{mg} / \mathrm{kg}$ NT-3 normalised the increase in resting $\left[\mathrm{Ca}^{2+}\right]_{\mathrm{i}}$. The amplitudes induced by depolarisation, caffeine and ATP $\left[\mathrm{Ca}^{2+}\right]_{\mathrm{i}}$ responses were reduced in small $(<30 \mu \mathrm{m}$ diameter) but not big $(>35 \mu \mathrm{m}$ diameter) neurones of L4-L6 DRG from streptozotocin-diabetic animals; the C5-L3 DRG were not similarly affected and the changes in the L4-L6 DRG were corrected by NT-3 treatment.

Conclusions/interpretation. Altered calcium homeostasis could be an early molecular marker linked to the onset of diabetic sensory neuropathy. This neurodegenerative index can be corrected by NT-3 therapy and should encourage further work aimed at understanding the mechanistic basis of these observations. [Diabetologia (2002) 45:560-570]

Keywords Diabetic neuropathy, neurotrophin, neurotrophin-3, dorsal root ganglia, calcium imaging, sensory neurone, purinoreceptor, caffeine.
Received: 5 November 2001 and in revised form: 10 December 2001

Corresponding author: Dr. A. Verkhratsky, School of Biological Sciences, University of Manchester, 1.124 Stopford Building, Oxford Road, Manchester, M13 9PT, UK, e-mail: alex.verkhratsky@man.ac.uk

Abbreviations: DRG Dorsal root ganglia; $\left[\mathrm{Ca}^{2+}\right]_{\mathrm{i}}$ internal $\mathrm{Ca}^{2+}$ concentration; NT-3, neurotrophin-3; STZ, streptozotocin
A variety of hyperglycaemia-induced secondary metabolic defects have been identified as possible causal factors in the aetiology of the symmetrical sensory polyneuropathy observed in diabetes mellitus. These include polyol pathway flux [1], protein glycosylation [2], oxidative stress [3] and impaired neurotrophic support [4]. Alteration of cytoplasmic calcium homeostasis and calcium signalling might also be responsible for neurodegenerative diabetic complications $[5,6]$. Studies have shown altered $\mathrm{Ca}^{2+}$ signalling in response to cell depolarisation in sensory 
[7-10] and dorsal horn [6, 11] neurones. These experiments, however, used a single fluorescence detector, which did not allow signals from neurones and non-neuronal (satellite) cells to be distinguished. Such a technical limitation could considerably affect the accuracy in determining the parameters of $\mathrm{Ca}^{2+}$ homeostasis. Moreover, only depolarisation-induced $\mathrm{Ca}^{2+}$ signals have been investigated up to now, and the parameters of $\mathrm{Ca}^{2+}$ responses activated by neurotransmitters can differ from the processes regulating homeostatic control of internal $\mathrm{Ca}^{2+}$ stores.

Additionally, the studies cited above did not distinguish between sensory neurones from different levels of the spinal cord. This is an important oversight when one considers that the longest sensory axons, i.e. those at the lumbar level, seem to be most susceptible to diabetes-induced neurodegeneration [12]. Therefore, the identification of neurodegenerative processes specific to lumbar sensory ganglia might provide insight into the aetiology of diabetic sensory polyneuropathy.

We have used real-time fluorescent video-imaging to probe for intracellular calcium $\left(\left[\mathrm{Ca}^{2+}\right]_{\mathrm{i}}\right)$ homeostasis in sensory neurones of cervical and lumbar dorsal root ganglia (DRG). We have found that in sensory neurones acutely isolated from streptozotocin (STZ)-diabetic rats there are selective alterations in $\left[\mathrm{Ca}^{2+}\right]_{\mathrm{i}}$ homeostasis in lumbar DRG versus ganglia from higher levels. Moreover, treatment with neurotrophin-3 (NT-3) reversed some of the observed alterations.

\section{Subjects and methods}

Induction of diabetes and NT-3 treatment. Male Wistar rats $(300 \mathrm{~g})$ were made diabetic by a single intraperitoneal injection of STZ $(55 \mathrm{mg} / \mathrm{kg}$; Sigma, Dorset, UK). Age-matched and weight-matched control groups were also set up. Tail blood glucose was assayed 3 days after injection using glucose test strips (BM-Accutest, Roche Diagnostics, Basel, Switzerland, UK) to confirm diabetes. All diabetic animals had blood glucose values higher than $30 \mathrm{mmol} / \mathrm{l}$. Rats were maintained for 8 to 14 weeks with free access to water and chow. One group of diabetic rats received subcutaneous injections of $5 \mathrm{mg} / \mathrm{kg}$ human recombinant NT-3 (a gift from Regeneron Pharmaceuticals, Tarry Town, N. Y., USA) three times weekly for the final 10 weeks of the 14-week diabetes study. Body weights for agematched control rats ranged from 530 to $710 \mathrm{~g}$, while all groups of diabetic rats and weight-matched rats were $290-445 \mathrm{~g}$ at the end of the study. In all diabetic animals motor nerve conductance velocity (MNCV) and sensory nerve conductance velocity (SNCV; as measured by H-reflex) were reduced. The efficacy of NT-3 treatment was confirmed by reversal of the SNCV deficit $[13,14]$ (data not shown). Morphometric analysis of the 14-week diabetic group showed no effect of diabetes on axon calibre or structure (for the largest axons of sural nerve). Rats were killed under pentobarbitol-induced anaesthesia and L4-L6 and C5-L3 DRG removed and used to prepare separate cultures.
Sensory neurone cultures. Animals were killed humanely according to the principles of laboratory animal care and United Kingdom legislation. DRG were immediately dissociated using a previously described method [15]. The cells were plated onto poly-L-ornithine-laminin-coated $1.1 \mathrm{~cm}$ glass coverslips in serum-free F12 medium (Life Technologies, Paisley, UK) at $37^{\circ} \mathrm{C}$ in a $95 \%$ air and $5 \% \mathrm{CO}_{2}$ humidified incubator. Cells were cultured for 3 to 4 hours and then assessed.

Fluorescence imaging of $\left[\mathrm{Ca}^{2+}\right]_{i}$. Isolated DRG cells were loaded with $\mathrm{Ca}^{2+}$ fluorescent probe, $5 \mu \mathrm{mol} / \mathrm{l}$ fura-2/AM, at room temperature in standard physiological saline (in $\mathrm{mmol} / \mathrm{l}$ ): $\mathrm{NaCl}-140, \mathrm{KCl}-3, \mathrm{CaCl}_{2}-2, \mathrm{MgCl}_{2}-2$, glucose - 10, $\mathrm{HEPES} / \mathrm{NaOH}-20, \mathrm{pH}$ 7.4. After loading, the cells were washed in normal saline for an additional $30 \mathrm{~min}$ to ensure the de-esterification of fura-2/AM. Glass coverslips with stained cells were transferred into the $500 \mu \mathrm{l}$ perfusion chamber mounted on the stage of an upright microscope (Olympus BX50WI, Tokyo, Japan) equipped with $20 \mathrm{x}$ water immersion objectives. The chamber was continuously superfused (at a rate of $5 \mathrm{ml} / \mathrm{min}$ ) with normal physiological solution at room temperature. The bath application of experimental solutions was done by switching the normal saline to specified solutions from one of eight reservoirs via a solenoid switching mechanism. High $\mathrm{KCl}$ solution contained (in $\mathrm{mmol} / \mathrm{l}$ ): $\mathrm{NaCl}-53$, $\mathrm{KCl}-90, \mathrm{CaCl}_{2}-2, \mathrm{MgCl}_{2}-2$, glucose -10 and HEPES/ $\mathrm{NaOH}-20, \mathrm{pH} 7.4$.

For fluorescence measurements the cells were alternately exposed to excitation light provided by a monochromator (Polychrom IV, TILL Photonics, Gräfelfing, Germany) at 340 and $380 \mathrm{~nm}$. Emitted fluorescence light was collected at $530 \pm 15 \mathrm{~nm}$ by a frame transfer cooled intensified charge coupled device (CCD) camera (Gene IV, Roper Scientific, Marlow, UK). The imaging data were acquired and analysed using MetaFluor/MetaMorph software (Universal Imaging, Downingtown, USA). The fura-2 signal was calibrated using an ionomycin-based in situ procedure [16]; the parameters $\mathbf{R}_{\min }, \mathbf{R}_{\max }$ and $\mathrm{K}^{*}$ were $0.2,1.0$ and $451 \mathrm{nmol} / 1$ respectively. All reagents were purchased from Sigma (Dorset, UK), and fura-2/AM was obtained from Molecular Probes (Eugene, Ore., USA).

Data analysis. Where appropriate, data were subjected to oneway ANOVA using the Statistical Package for Social Scientists (SPSS/PC + ; SPSS, Chicago, Ill., USA). Where the F ratio gave $p<0.05$, comparisons between individual group means were made by Scheffe's multiple range test at significance of $p=0.05$. Single comparisons between 14 -week diabetic and NT-3 treated 14-week diabetic groups were made using a student's $t$ test at significance $p=0.01$.

\section{Results}

Separation of $\left[\mathrm{Ca}^{2+}\right]_{i}$ responses between neuronal and non-neuronal cells. Acutely isolated preparations of DRG contain several cell types and require specific attention in segregating the responses arising from different cellular elements. Apart from Schwann cells, which could be identified by their specific morphology, and which are not the subject of this study, the cellular preparation of DRG had two major cell types. These were neurones and peri-neuronal satellite (or fibroblast-like) cells, most likely representing another subset of glia [17, 18]. These cells appeared 


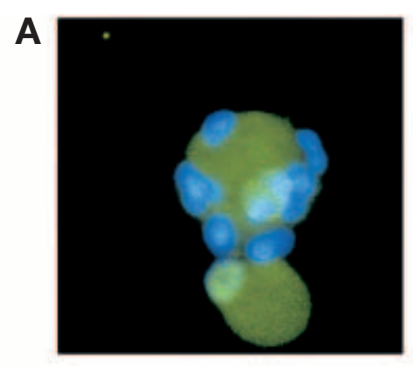

B
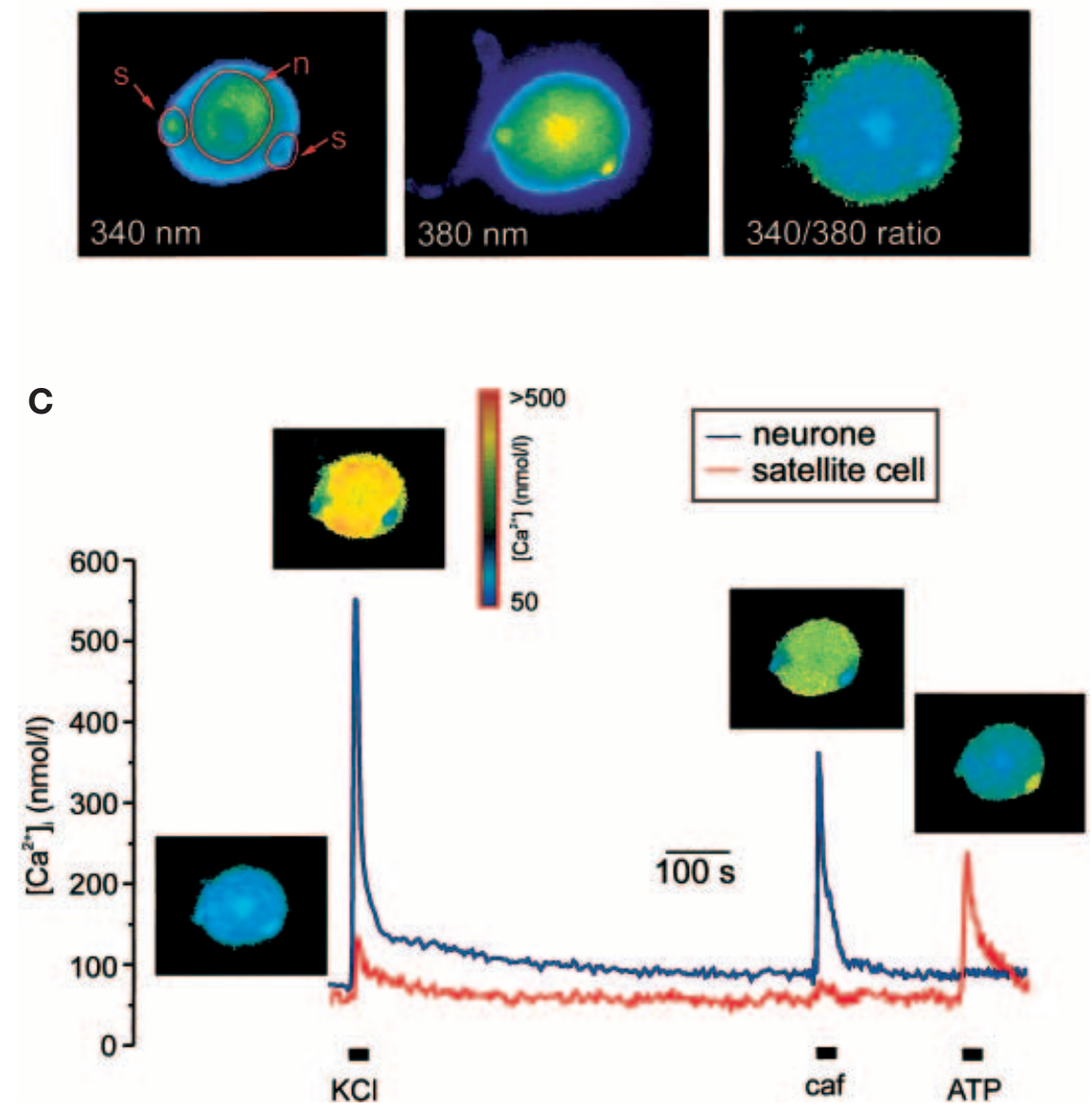

Fig. 1 (A-C). Separation of $\left[\mathrm{Ca}^{2+}\right]_{\mathrm{i}}$ dynamics in sensory neurones and attached satellite cells. A Immunocytochemical staining of a neurone with neurone-specific anti-PGP9.5 antibody and co-staining with DAPI (nuclear staining) showing a cluster of non-neurones associated with the neurone. B Digital images of a DRG neurone with two attached satellite cells taken when illuminating the cells at 340 and $380 \mathrm{~nm}$, as well as a ratio image, from which the actual $\mathrm{Ca}^{2+}$ concentration was calculated. The regions of interest used for acquisition of $\left[\mathrm{Ca}^{2+}\right]_{i}$ kinetics are indicated on the $340 \mathrm{~nm}$ image; $\mathrm{s}-$ denotes the satellite cell, $\mathrm{n}$ - neuronal somata. $\mathbf{C}\left[\mathrm{Ca}^{2+}\right]_{\mathrm{i}}$ dynamics recorded from cells shown in (A) in response to depolarisation (30 s application of $90 \mathrm{mmol} / 1 \mathrm{KCl}$ solution), activation of intracellular $\mathrm{Ca}^{2+}$ release (30 s application of $20 \mathrm{mmol} / \mathrm{l}$ caffeine) and activation of purinoreceptors (30 s application of $100 \mu \mathrm{mol} / \mathrm{l}$ ATP). Note clear separation of neuronal vs satellite cell responses either in free form, or were firmly attached to neurones (Fig. 1A, B). In the latter, the separation of neurone-derived signals from those originating in satellite cells was of vital importance.

A typical image of a DRG neurone with attached satellite cells which were specifically immunostained using the neuronal marker protein gene product (PGP) 9.5 and counterstained with DAPI to indicate associated nuclei is shown (Fig.1A). When loaded with Fura-2/AM the satellite cells demonstrated higher fluorescent staining at both $340 \mathrm{~nm}$ and 380 $\mathrm{nm}$ excitation wavelength (Fig. 1B), reflecting probably a larger amount of the dye accumulated by these cells. As the amount of trapped dye depends on cell volume [19], the smaller cells tend to accumulate higher amounts of the probe. This property allowed 
Big neurones
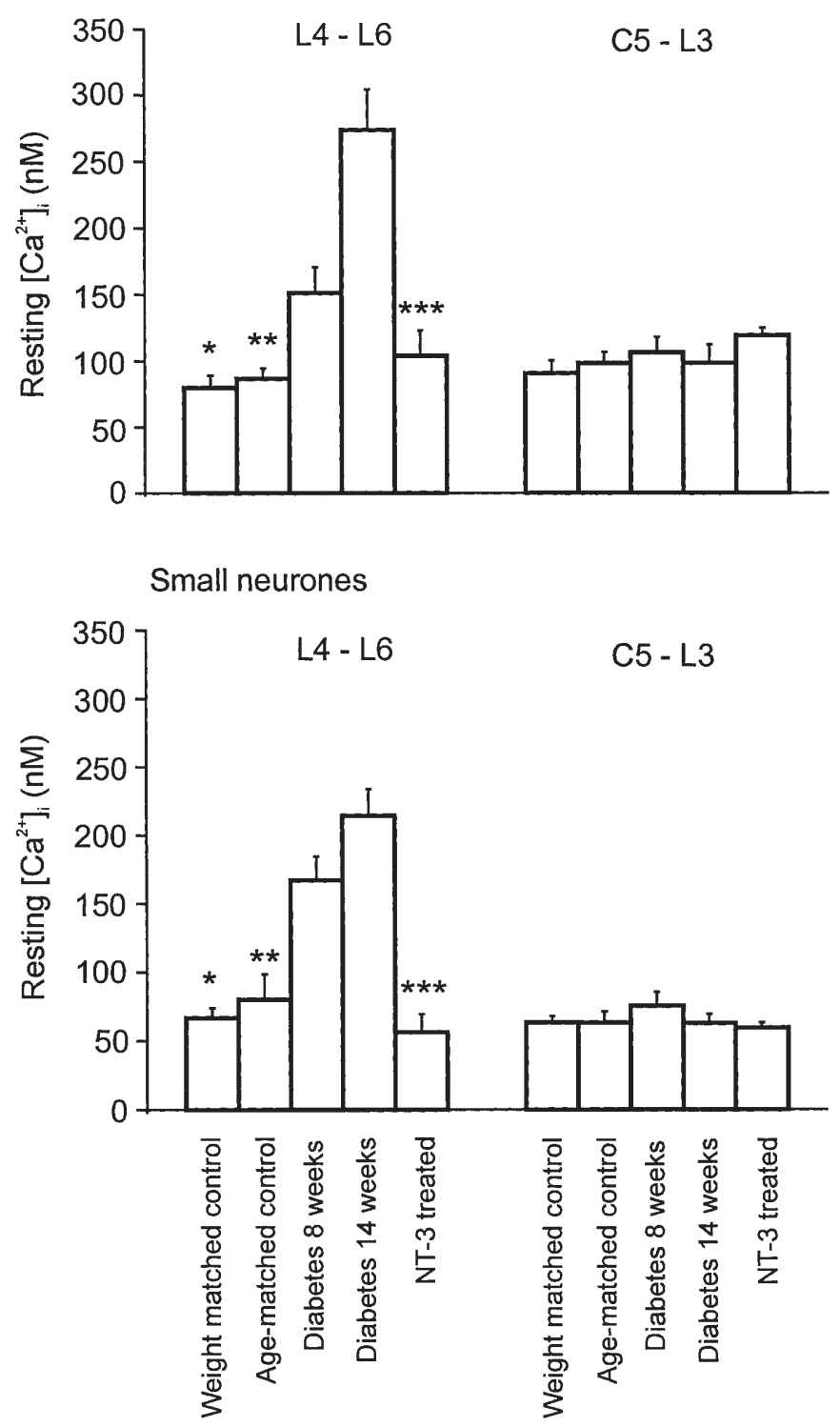

Fig. 2. Resting $\left[\mathrm{Ca}^{2+}\right]_{\mathrm{i}}$ in small and big sensory neurones isolated from lumbar (L4 - L6) and cervical/lumbar (C5 - L3) ganglia in different experimental groups. ${ }^{*} p<0.05$ for weight-matched control vs 8 weeks and 14 -week diabetic; **aged-matched vs 8-week and 14-week diabetic (both by one-way ANOVA); *** $p<0.01$ vs 14 -week diabetic (student's $t$ test). The $n$ value varied between 70 and 105

us to localise the satellite cells on live images and place region of interest for kinetic $\left[\mathrm{Ca}^{2+}\right]_{\mathrm{i}}$ analysis accordingly. Satellite cells and neurones had distinct $\left[\mathrm{Ca}^{2+}\right]_{\mathrm{i}}$ dynamics in response to different stimuli (Fig. 1C). Cell depolarisation (by bath application of $90 \mathrm{mmol} / 1 \mathrm{KCl}$ ) or activation of $\mathrm{Ca}^{2+}$ release from intracellular stores (by $20 \mathrm{mmol} / \mathrm{l}$ caffeine) triggered large $\left[\mathrm{Ca}^{2+}\right]_{i}$ increases in the majority of neurones but barely affected satellite cells. In contrast, extracellular application of $100 \mu \mathrm{mol} / \mathrm{l}$ ATP readily in- duced $\left[\mathrm{Ca}^{2+}\right]_{\mathrm{i}}$ increase in satellite cells. Thus, using this imaging system we were able to segregate physiological responses from closely associated satellite cells and neurones.

$\mathrm{Ca}^{2+}$ homeostasis in neurones from L4-L6 ganglia and NT-3 reverses these changes. To characterise the status of the $\mathrm{Ca}^{2+}$ homeostatic machinery in sensory neurones acutely isolated from STZ-diabetic rats we probed several systems known to activate distinct $\mathrm{Ca}^{2+}$ signalling pathways. For this purpose we analysed parameters of $\left[\mathrm{Ca}^{2+}\right]_{\mathrm{i}}$ responses triggered by (i) cell depolarisation; (ii) activation of $\mathrm{Ca}^{2+}$ release from the endoplasmic reticulum (ER) calcium stores by caffeine and (iii) activation of purinoreceptors by ATP. Each stimulation protocol was used separately for the cell groups delineated below. For each stimulation protocol the following parameters were measured: (i) percentage of cells responding to a given stimuli; (ii) the amplitude of $\mathrm{Ca}^{2+}$ increase and (iii) for depolarisation-induced $\mathrm{Ca}^{2+}$ responses we also measured the recovery time of the $\left[\mathrm{Ca}^{2+}\right]_{\mathrm{i}}$ transient; the latter was expressed as the time required for recovery of $\left[\mathrm{Ca}^{2+}\right]_{\mathrm{i}}$ to $75 \%$ of the peak of the $\mathrm{Ca}^{2+}$ transient $\left(\tau_{75}\right)$. In addition we also investigated whether STZ-induced diabetes affects resting level of $\left[\mathrm{Ca}^{2+}\right]_{i}$ in sensory neurones.

All these parameters were measured in neurones isolated from five groups of animals: (i) weight-matched control animals; (ii) age-matched control animals; (iii) 8-week STZ-diabetic animals; (iv) 14-week STZ-diabetic animals and (v) 14-week STZ-diabetic animals treated subcutaneously with $5 \mathrm{mg} / \mathrm{kg}$ human recombinant NT-3 for the final 10 weeks. All diabetes-induced changes in $\mathrm{Ca}^{2+}$ homeostasis were restricted to neurones only, as we failed to identify any $\left[\mathrm{Ca}^{2+}\right]_{\mathrm{i}}$ changes in satellite cells from any of the experimental groups. As the expression of various components of $\mathrm{Ca}^{2+}$ homeostatic machinery differs between proprioceptive and nociceptive neurones [20] we further divided all neurones into two groups: big (mostly proprioceptive or mechanoreceptive) neurones with cell diameter $>35 \mu \mathrm{m}$ and small (mostly nociceptive) neurones with cell diameter $<30 \mu \mathrm{m}$.

Resting $\left[\mathrm{Ca}^{2+}\right]_{i}$. We found that diabetes produced a pronounced increase in resting $\left[\mathrm{Ca}^{2+}\right]_{\mathrm{i}}$, which became larger with an increased duration of diabetes. This increase in resting $\left[\mathrm{Ca}^{2+}\right]_{\mathrm{i}}$ was observed in both big and small neurones isolated from L4-L6 DRG. The resting $\left[\mathrm{Ca}^{2+}\right]_{\mathrm{i}}$ in cells obtained from C5-L3 DRG was not affected (Fig. 2). The diabetes-induced changes in resting $\left[\mathrm{Ca}^{2+}\right]_{\mathrm{i}}$ in L4-L6 DRG neurones were completely reversed by treatment with NT-3.

Depolarisation induced $\left[\mathrm{Ca}^{2+}\right]_{i}$ responses. To characterise the $\left[\mathrm{Ca}^{2+}\right]_{i}$ increase evoked by the depolarisation of the neuronal membrane, we stimulated the 

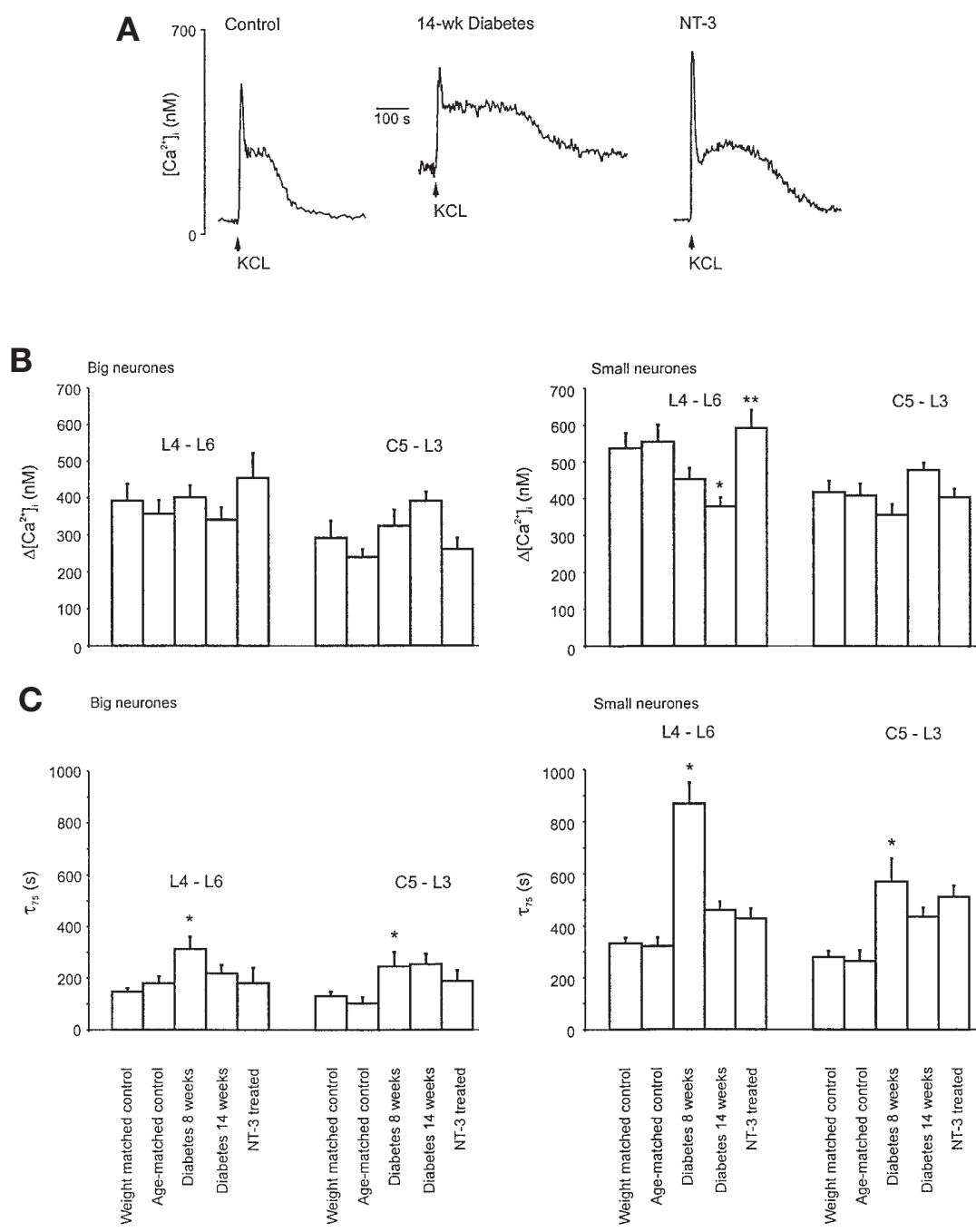

Fig. 3 (A-C). Effects of diabetes and NT-3 treatment on depolarisation-induced $\left[\mathrm{Ca}^{2+}\right]_{\mathrm{i}}$ transients in neurones isolated from lumbar (L4 - L6) and cervical-lumbar (C5 - L3) DRGs. A Examples of $\left[\mathrm{Ca}^{2+}\right]_{\mathrm{i}}$ transients in response to $10 \mathrm{~s}$ application of $90 \mathrm{mmol} / \mathrm{K} \mathrm{KCl}$ (time of application are indicated by arrows) in neurones isolated from lumbar DRGs of control, 14-week diabetic and NT-3 treated animals. B Average values of amplitude of depolarisation-induced $\left[\mathrm{Ca}^{2+}\right]_{\mathrm{i}}$ transients $\left(\Delta\left[\mathrm{Ca}^{2+}\right]_{\mathrm{i}}\right)$ in small and big neurones isolated from lumbar (L4 - L6) and cervical-lumbar (C5 - L3) DRGs obtained from different experimental groups as indicated on the graph. ${ }^{*} p<0.05$ vs weightand age-matched control animals (one-way ANOVA); ${ }^{* *} p<0.01$ vs 14 -week diabetic (student's $t$ test). The $n$ value varied between 78 and 140. C Average values of time of $75 \%$ of the recovery of depolarisation-induced $\left[\mathrm{Ca}^{2+}\right]_{\mathrm{i}}$ transients $\left(\tau_{75}\right)$ in small and big neurones isolated from lumbar (L4 - L6) and cervical-lumbar (C5 - L3) DRGs obtained from different experimental groups as indicated on the graph. ${ }^{*} p<0.01$ vs weight- and age-matched control animals (one-way ANOVA). (student's $t$ test). The $n$ value varied between 78 and 140

cells with a $30 \mathrm{~s}$ application of extracellular solution containing $90 \mathrm{mmol} / \mathrm{l}$ of $\mathrm{KCl}$. Such an increase in extracellular potassium (from $3 \mathrm{mmol} / \mathrm{l}$ to $90 \mathrm{mmol} / \mathrm{l}$ ) effectively clamped the membrane potential at about $-15 \mathrm{mV}$ for the duration of $\mathrm{KCl}$ exposure. This in turn activated voltage-gated $\mathrm{Ca}^{2+}$ channels thus producing massive $\mathrm{Ca}^{2+}$ influx into the cytosol. We found that STZ-diabetes primarily affected depolarisationinduced $\left[\mathrm{Ca}^{2+}\right]_{\mathrm{i}}$ responses in small DRG neurones (Fig. 3A, B). Moreover, similar to the changes in resting $\left[\mathrm{Ca}^{2+}\right]_{i}$, the amplitude of depolarisation-induced $\mathrm{Ca}^{2+}$ transients decreased specifically in cells isolated from L4-L6 DRG (Fig. 3B), but not in cells from C5L3 DRG. This decrease was fully reversed by NT-3 treatment. In addition, we found a profound retardation of the recovery of depolarisation-induced $\left[\mathrm{Ca}^{2+}\right]_{i}$ transients in both big and small neurones isolated from diabetic rats (Fig. 3C). The slow down of $\left[\mathrm{Ca}^{2+}\right]_{\mathrm{i}}$ recovery was apparent in all cell groups, being the most prominent in small neurones isolated from L4-L6 DRG after 8 weeks of diabetes.

Caffeine-induced $\left[\mathrm{Ca}^{2+}\right]_{i}$ responses. The ER calcium store is an important source for $\mathrm{Ca}^{2+}$ signals in nerve 

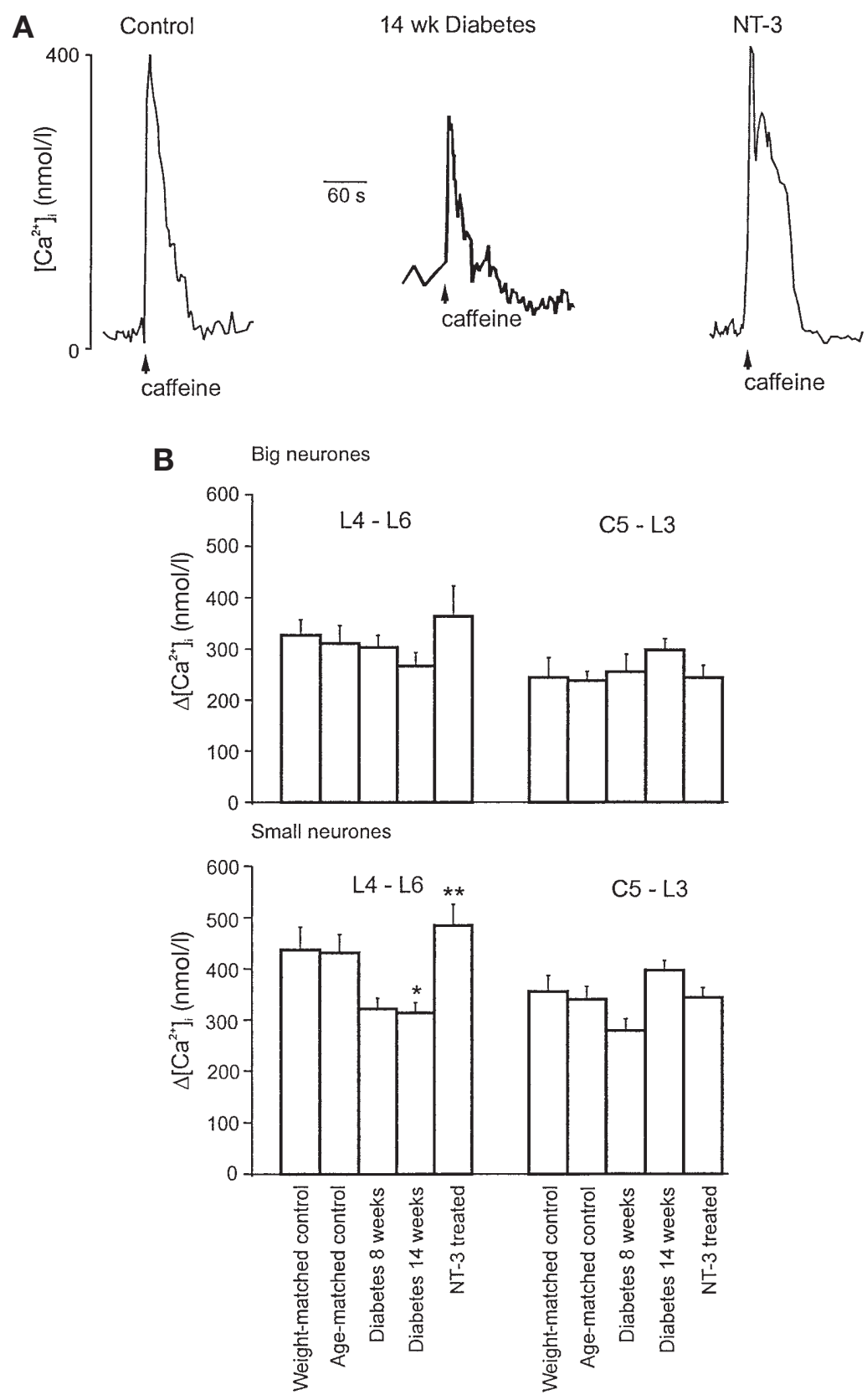

Fig. 4 (A, B). Effects of diabetes and NT-3 treatment on caffeine-induced $\left[\mathrm{Ca}^{2+}\right]_{\mathrm{i}}$ transients in neurones isolated from lumbar (L4 - L6) and cervical-lumbar (C5 - L3) DRGs. A Examples of $\left[\mathrm{Ca}^{2+}\right]_{\mathrm{i}}$ transients in response to $30 \mathrm{~s}$ application of $20 \mathrm{mmol} / \mathrm{l}$ caffeine (beginning of applications are indicated by arrows) in neurones isolated from lumbar DRGs in control, 14 weeks diabetic and NT-3 treated animals. B Average values for amplitude of caffeine-induced $\left[\mathrm{Ca}^{2+}\right]_{\mathrm{i}}$ transients $\left(\left[\mathrm{Ca}^{2+}\right]_{\mathrm{i}}\right)$ in small and big neurones isolated from lumbar (L4 - L6) and cervical-lumbar (C5 - L3) DRGs obtained from different experimental groups as indicated on the graph. ${ }^{*} p<0.05$ vs weightand age-matched control animals (one-way ANOVA); $* * p<0.01$ vs 14 -week diabetic (student's $t$ test) cells $[21,22]$. To initiate $\mathrm{Ca}^{2+}$ release from the endoplasmic reticulum we treated DRG neurones with $20 \mathrm{mmol} / \mathrm{l}$ caffeine (30 s application, Fig. 4). The latter is known to activate $\mathrm{Ca}^{2+}$-gated $\mathrm{Ca}^{2+}$ release channels (ryanodine receptors) resident in the endoplasmic reticulum membrane $[16,23]$. In L4-L6 DRG neurones, the percentage of cells responding to caffeine (when the amplitude of the $\left[\mathrm{Ca}^{2+}\right]_{\mathrm{i}}$ increase was triggered by drug application exceeded $50 \mathrm{nmol} / \mathrm{l}$ ) decreased from $80 \%$ in the control groups to $50 \%$ after 14 weeks of diabetes and NT-3 treatment was effective in normalising the cell number responding to caffeine (data not shown). In the C5-L3 DRG there was little evidence of any change in the number of cells responding to caffeine. The amplitude of the caffeine-induced $\left[\mathrm{Ca}^{2+}\right]_{\mathrm{i}}$ increase was most decreased in 

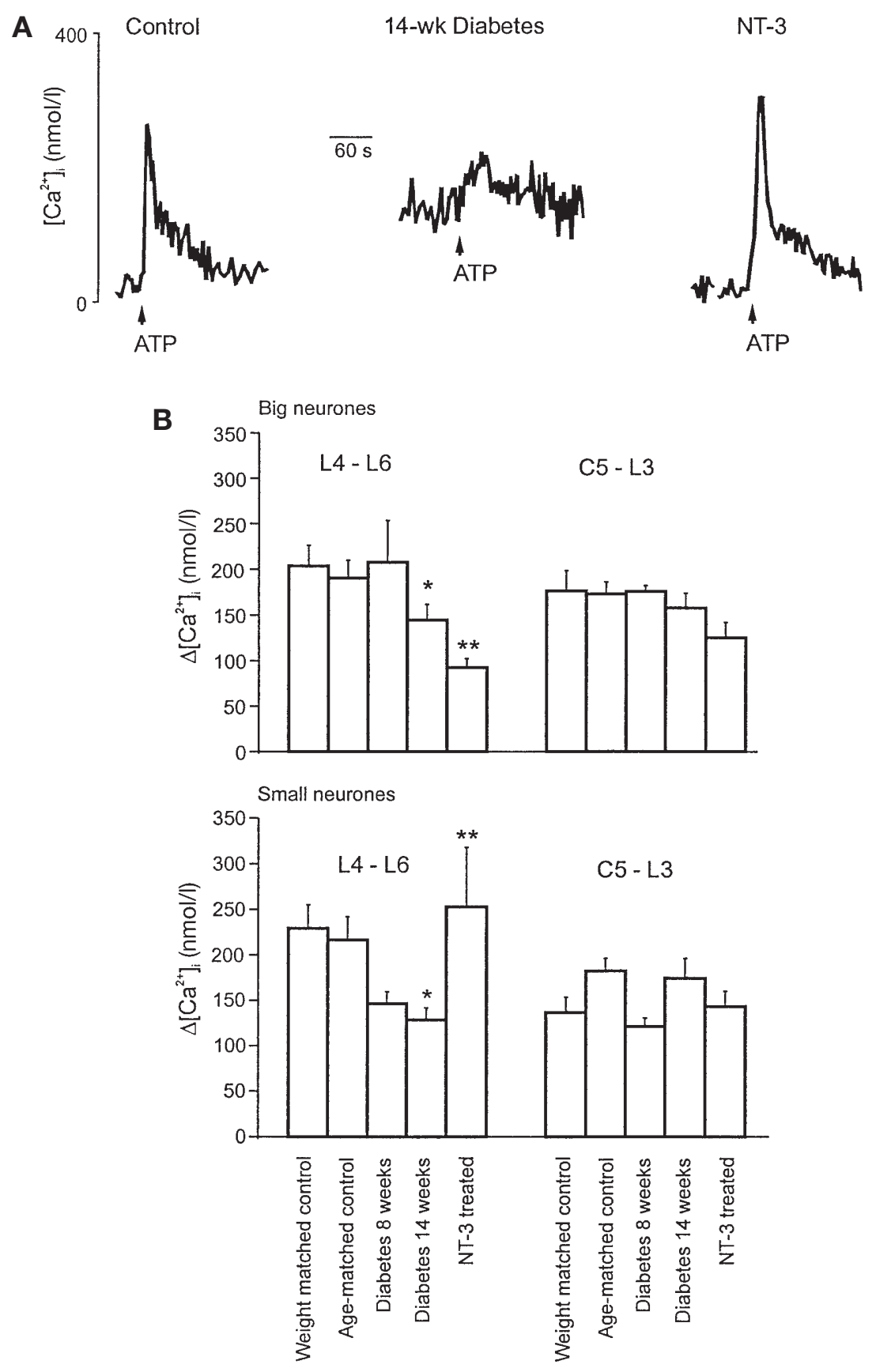

Fig. 5 (A, B). Effects of diabetes and NT-3 treatment on ATPinduced $\left[\mathrm{Ca}^{2+}\right]_{\mathrm{i}}$ transients in neurones isolated from lumbar (L4 - L6) and cervical-lumbar (C5 - L3) DRGs. A Examples of $\left[\mathrm{Ca}^{2+}\right]_{\mathrm{i}}$ transients in response to $30 \mathrm{~s}$ application of $100 \mu \mathrm{mol} / 1$ ATP (beginning of applications are indicated by arrows) in neurones isolated from lumbar DRGs in control, 14 weeks diabetic and NT-3 treated animals. B Average values of amplitude of ATP-induced $\left[\mathrm{Ca}^{2+}\right]_{\mathrm{i}}$ transients $\left(\Delta\left[\mathrm{Ca}^{2+}\right]_{\mathrm{i}}\right)$ in big and small neurones isolated from lumbar (L4 - L6) and cervical-lumbar (C5 - L3) DRGs obtained from different experimental groups as indicated on the graph. $* p<0.05$ vs weightand age-matched control animals (one-way ANOVA); $* * p<0.01$ vs 14-week diabetic (student's $t$ test) the small neurones isolated from L4-L6 DRGs (Fig.4) and NT-3 treatment fully reversed this decrease. A similar tendency (although not reaching statistical significance) towards a decrease in the amplitude of caffeine-evoked $\left[\mathrm{Ca}^{2+}\right]_{\mathrm{i}}$ responses was observed in large neurones from L4-L6 ganglia. To the contrary, the amplitudes of caffeine-induced $\left[\mathrm{Ca}^{2+}\right]_{\mathrm{i}}$ increase measured from C5-L3 DRG cells were not affected by experimental diabetes. NT-3 had no effect on the cell number responding to caffeine or the amplitude of the $\left[\mathrm{Ca}^{2+}\right]_{\mathrm{i}}$ transient in the C5-L3 DRG neurones.

ATP-induced $\left[\mathrm{Ca}^{2+}\right]_{i}$ responses. DRG neurones express several types of purinoreceptors of both iono- 
tropic $\left(\mathrm{P}_{2 \mathrm{X}}\right)$ and metabotropic $\left(\mathrm{P}_{2 \mathrm{Y}}\right)$ families [24-26]. All these receptors are stimulated by extracellular administration of ATP, and their activation results in complex $\left[\mathrm{Ca}^{2+}\right]_{i}$ responses driven by $\mathrm{Ca}^{2+}$ entry through $\mathrm{P}_{2 X}$ receptors and plasmalemmal $\mathrm{Ca}^{2+}$ channels [27] and inositol-trisphosphate ( $\left.\mathrm{InsP}_{3}\right)$-mediated $\mathrm{Ca}^{2+}$ release from the ER Ca ${ }^{2+}$ stores [28]. Not every DRG neurone expresses functional purinoreceptors and under control conditions only $49 \%$ of big neurones and $57 \%$ of small neurones from L4-L6 and $52 \%$ of big neurones and $61 \%$ of small neurones from C5-L3 ganglia preparations responded to the extracellular administration of $100 \mu \mathrm{mol} / 1$ ATP (the application of the agonist lasted $30 \mathrm{~s}$ ) with an increase in $\left[\mathrm{Ca}^{2+}\right]_{\mathrm{i}}$. The cells were considered responding when the amplitude of $\left[\mathrm{Ca}^{2+}\right]_{\mathrm{i}}$ increase evoked by ATP exceeded $30 \mathrm{nmol} / \mathrm{l}$. In diabetic animals we found a substantial decrease in the number of cells sensitive to ATP: only about $1 / 3$ of all the neurones (L4-L6: big neurones $27 \%$, small neurones $38 \%$; C5-L3: big neurones $26 \%$, small neurones $29 \%$ after 14 weeks of diabetes) retained their ability to generate a $\left[\mathrm{Ca}^{2+}\right]_{\mathrm{i}}$ signal in response to stimulation of purinoreceptors. This decrease was not reversed by NT-3 treatment. The amplitude of ATP-induced $\left[\mathrm{Ca}^{2+}\right]_{\mathrm{i}}$ increase, however, was most affected after 8 and 14 weeks of diabetes in small DRG neurones isolated from L4-L6 ganglia, and the NT-3 treatment restored it to control values (Fig. 5). In big neurones isolated from L4-L6 DRG's we also observed a decrease in the amplitude of ATP-induced $\left[\mathrm{Ca}^{2+}\right]_{\mathrm{i}}$ responses after 14 weeks of diabetes, however this decrease was insensitive to NT-3 (Fig. 5B). There was no significant alteration in ATP-induced $\left[\mathrm{Ca}^{2+}\right]_{\mathrm{i}}$ transients in the small (or big) neurones from C5-L3 DRG.

\section{Discussion}

High resolution video-imaging of cultured sensory neurones isolated from STZ-diabetic rats showed that diabetes markedly affects $\mathrm{Ca}^{2+}$ homeostasis in neurones isolated from the L4-L6 DRG. Neurones from C5-L3 DRG were not similarly affected. This neurodegenerative index correlates with the pathophysiology of diabetic sensory neuropathy where neurones with the longest axons are most prone to neurodegeneration [12]. Whereas the C5-L3 DRG cultures would contain some neurones with long axons innervating the forelimb and hindlimb of the rat, the majority of the neurones cultured were from the thoracic region and would normally exhibit shorter axons in vivo. Furthermore, our data point out that the disruption of $\mathrm{Ca}^{2+}$ signalling processes was more prominent in small (nociceptive) neurones from L4L6 ganglia.

Diabetes altered $\mathrm{Ca}^{2+}$ homeostasis as judged by a substantial increase in resting $\left[\mathrm{Ca}^{2+}\right]_{i}$ and prolonga- tion of the recovery from depolarisation-induced $\mathrm{Ca}^{2+}$ loads. The most prominent change, exclusively confined to cells obtained from L4-L6 DRG, was a more than twofold increase in the resting $\left[\mathrm{Ca}^{2+}\right]_{\mathrm{i}}$. The former is a parameter very closely associated with neurodegeneration in a number of neuronal systems [5]. The increase in resting $\left[\mathrm{Ca}^{2+}\right]_{i}$ coincided with a decrease in the amplitude of the depolarisation-induced $\left[\mathrm{Ca}^{2+}\right]_{i}$ increase, which was detectable exclusively in small neurones from L4-L6 DRG. The latter could reflect a decrease in $\mathrm{Ca}^{2+}$ channel availability due to $\mathrm{Ca}^{2+}$-dependent inactivation at high resting $\left[\mathrm{Ca}^{2+}\right]_{\mathrm{i}}$. The actual density of $\mathrm{Ca}^{2+}$ channels was reported to be increased in diabetic sensory neurones [7] and this might act in a compensatory nature. Treatment with NT-3 completely prevented both the increase in resting $\left[\mathrm{Ca}^{2+}\right]_{\mathrm{i}}$ and the decrease in the amplitude of $\left[\mathrm{Ca}^{2+}\right]_{i}$ increase in response to depolarisation. We also found a marked prolongation in recovery time of depolarisation-induced $\left[\mathrm{Ca}^{2+}\right]_{\mathrm{i}}$ transients. This increase in recovery time was observed in all groups of neurones being the most prominent in small cells isolated from L4-L6 DRG. This parameter peaked after 8 weeks of STZ-induced diabetes, after 14 weeks of diabetes the recovery time showed the tendency to return to control values.

Experimental diabetes also markedly affected ER calcium stores in DRG neurones. This was demonstrated by a decrease in the amplitude of the caffeine-induced $\left[\mathrm{Ca}^{2+}\right]_{\mathrm{i}}$ increase observed specifically for small neurones from L4-L6 DRGs. Once more, the most prominent changes were observed in small neurones where a decrease in the amplitude of caffeine-induced $\left[\mathrm{Ca}^{2+}\right]_{\mathrm{i}}$ increase was statistically significant already after 8 weeks of diabetes. In large neurones a similar, non-significant, decrease was observed after 14 weeks. The reduced amplitude of the caffeine-induced $\mathrm{Ca}^{2+}$ release from intracellular stores in L4-L6 DRG neurones of STZ-diabetic rats were fully reversed by NT-3 treatment.

We also found that experimental diabetes was associated with a decrease (from approximately $57 \%$ down to $30 \%$ ) in the number of DRG neurones expressing functional purinoreceptors. This decrease was observed in cells from both the C5-L3 and L4L6 DRG cultures. In the cells that did respond to ATP there was a decline in the ATP-induced $\mathrm{Ca}^{2+}$ transient in diabetes which was present in cells of L4-L6 ganglia and was completely reversed by NT-3 treatment in only the small neurones.

Such a down-regulation of both functional purinoreceptor expression and ATP-induced $\mathrm{Ca}^{2+}$ transients might have a pathophysiological relevance, as these receptors are believed to be associated with nociception [24] and STZ-diabetic rats show mechanical hyperalgaesia and tactile allodynia at these time points $[29,30]$. The mechanisms of regulation of expression of the different purinoreceptors have not been stud- 
ied in sensory neurones, however, expression could be dependent upon a supply of neurotrophic factors. Studies in STZ-diabetic rats show decreased target tissue expression and retrograde axonal transport of nerve growth factor (NGF) [31-33] and NT-3 [34]. Additionally, glial cell line-derived neurotrophic factor (GDNF) has been shown to rescue STZ-diabetes induced deficits in terminal arborisation in the dorsal horn of non-peptidergic neurones suggesting sub-optimal GDNF-dependent trophic support [35]. All of these growth factors are recognised as being neurotrophic factors for DRG sensory neurones, many of which express purinoreceptors, and NGF and GDNF have been shown to up-regulate $\mathrm{P}_{2 \mathrm{X}(3)}$ in sensory neurones [36].

In this study we elected to treat diabetic rats with NT-3 because previous studies have shown this growth factor to reverse physiological and morphological deficits in sensory neurones without inducing any unwanted side effects [13]. The ability of NT-3 to completely reverse most of the diabetes-induced alterations in calcium homeostasis was unexpected because only approximately $20 \%$ of sensory neurones in lumbar DRG express trkC receptors and, additionally, the small population of cells are not believed to express any trkC receptors [37]. However, at the dose used, $5.0 \mathrm{mg} / \mathrm{kg}$, NT-3 could be exerting effects on calcium homeostasis in a wide range of sensory neurones via binding to trkC, trkA and/or p $75^{\mathrm{NTR}}[38,39]$. NT-3 is known to be the most promiscuous neurotrophin with the ability to signal via trk receptors other than trkC. Sensory neurone deficits in NT-3 knockout mice are more severe than in trkC knockout mice, indicating that NT-3 can elicit its responses via receptors other than trkC [40]. Studies have shown NT-3 activation of trkA in NIH3T3 cells [41] and NT-3 activation of trkA and induction of neuritogenesis in primary sympathetic neurones [39]. Additionally, the insert-containing isoform of trkA is preferentially activated by NT-3, hence the isoforms of the receptor expressed are important in determining the signalling response [42]. It has been proposed that the majority of primary sensory neurones that express trkA, express the NT-3-susceptible, insert-containing isoform [43]. In adult rats treated with systemic NT-3, it is therefore feasible that NT-3 is acting via both trkA and trkC in the DRG. Therefore, the NT-3-dependent reversal of deficits in $\mathrm{Ca}^{2+}$ homeostasis in small neurones is probably occurring in the peptidergic, NGF-dependent population that express trkA. There is no evidence to support the notion that NT-3 might be acting on the non-peptidergic, GDNF-dependent population of small neurones.

Cellular mechanisms of alteration of $\mathrm{Ca}^{2+}$ homeostasis upon development of diabetes are not clear. The profound change in resting $\left[\mathrm{Ca}^{2+}\right]_{\mathrm{i}}$ implies a quite dramatic modification in basic $\mathrm{Ca}^{2+}$ homeostatic sys- tems, possibly involving alterations in expression of cytoplasmic $\mathrm{Ca}^{2+}$ buffering/extrusion systems. A proposed impairment in function of such systems is supported by the remarkable retardation in $\left[\mathrm{Ca}^{2+}\right]_{\mathrm{i}}$ recovery after depolarisation. This prolongation of recovery mostly results from a dramatic increase in the plateau of the $\left[\mathrm{Ca}^{2+}\right]_{\mathrm{i}}$ transient, possibly indicating a malfunction in mitochondrial $\mathrm{Ca}^{2+}$ uptake/release [44]. Furthermore, an impaired ER calcium buffering can also contribute to the prolongation of $\left[\mathrm{Ca}^{2+}\right]_{\mathrm{i}}$ signals.

A key question is why such homeostatic $\mathrm{Ca}^{2+}$ mechanisms are impaired in the L4-L6 DRG neurones but not in the C5-L3 neurones? We predict that with increasing duration of STZ-diabetes the C5-L3 DRG neurones would also show impaired $\mathrm{Ca}^{2+}$ homeostasis. The cause of the accelerated rate of dysfunction in the L4-L6 DRG neurones could be related to impaired signalling between cell body and target tissue (in both the retrograde and anterograde directions) since an increase in the distance any signal has to travel is one obvious parameter that separates the L4-L6 DRG from the C5-L3 DRG. Neurotrophins regulate cell phenotype via anterograde/retrograde transport-mediated processes and, therefore, the effects of impaired neurotrophin support could be more severe in neurones with long axons and might underlie the altered $\mathrm{Ca}^{2+}$ homeostasis observed. The ability of NT-3 to normalise many of these parameters supports this notion. Neurotrophins, such as NGF and NT-3, could regulate expression/function of proteins that control $\mathrm{Ca}^{2+}$ buffering in the mitochondria and ER and, therefore, a deficient supply of trophins would be predicted to result in impaired $\mathrm{Ca}^{2+}$ homeostasis. This lack of trophic support might also impinge on the smaller neurones more effectively than in larger neurones and thus explain why calcium homeostasis is more profoundly impaired in small versus large neurones. Additionally, large neurones can have more efficient in-built protective mechanisms that are activated upon loss of trophic support (i.e., induced by axotomy or diabetes). For example, autocrine production of BDNF occurs in large neurones upon axotomy and mRNA for $\mathrm{BDNF}$ is increased in DRG of diabetic rats [37, 45]. This induction of autocrine neurotrophic support could protect these cells from damaging alterations in calcium homeostasis.

In summary, at 8 to 14 weeks of diabetes there is an alteration of $\mathrm{Ca}^{2+}$ homeostasis in sensory neurones which is specific for the L4-L6 DRG. Such neurones have the longest axons and it is these neurones which are the most sensitive targets of diabetes-induced axonopathy. Therefore, these changes in $\mathrm{Ca}^{2+}$ homeostasis could be an early marker for diabetes-linked neurological complications and further investigation into mechanisms might reveal important aetiological events. 
Acknowledgements. This work was funded by grants from Diabetes UK (P. Fernyhough and A. Verkhratsky) and the Juvenile Diabetes Research Foundation (P. Fernyhough). T-J Huang was supported by an Overseas Research Scholarship. We thank Prof. David Tomlinson and Mr. Luke G. Eckersley for carrying out the sensory nerve conduction velocity measurements. We thank Dr. T. Purves for providing the stained image of a neurone for Figure 1A.

\section{References}

1. Tomlinson DR, Willars GB, Carrington AL (1992) Aldose reductase inhibitors and diabetic complications. Pharmacol Ther 54: 151-194

2. Brownlee M (1994) Glycation and diabetic complications. Diabetes 43: 836-841

3. Van Dam PS, Bravenboer B (1997) Oxidative stress and antioxidant treatment in diabetic neuropathy. Neurosci Res 21: 41-48

4. Fernyhough P, Tomlinson DR (1999) The therapeutic potential of neurotrophins for the treatment of diabetic neuropathy. Diabetes Rev 7: 300-311

5. Biessels G, Gispen WH (1996) The calcium hypothesis of brain aging and neurodegenerative disorders: Significance in diabetic neuropathy. Life Sci 59: 379-387

6. Voitenko NV, Kostyuk EP, Kruglikov IA, Kostyuk PG (1999) Changes in calcium signalling in dorsal horn neurons in rats with streptozotocin-induced diabetes. Neuroscience 94: 887-890

7. Hall KE, Sima AAF, Wiley JW (1995) Voltage dependent calcium currents are enhanced in rat dorsal root ganglion neurones from the Bio/Bred Worchester diabetic rats. J Physiol (Lond) 486: 313-322

8. Hall KE, Sima AAF, Wiley JW (1996) Opiate-mediated inhibition of calcium signaling is decreased in DRG neurons from the diabetic $\mathrm{BB} / \mathrm{W}$ rat. J Clin Invest 97: 1165-1172

9. Kostyuk E, Pronchuk N, Shmigol A (1995) Calcium signal prolongation in sensory neurones of mice with experimental diabetes. Neuroreport 6: 1010-1012

10. Kostyuk E, Svichar N, Shishkin V, Kostyuk P (1999) Role of mitochondrial dysfunction in calcium signalling alterations in dorsal root ganglion neurons of mice with experimentally-induced diabetes. Neuroscience 90: 535-541

11. Voitenko NV, Kruglikov IA, Kostyuk EP, Kostyuk PG (2000) Effect of streptozotocin-induced diabetes on the activity of calcium channels in rat dorsal horn neurons. Neuroscience 95: 519-524

12. Thomas PK, Tomlinson DR (1992) Diabetic and hypoglycaemic neuropathy. In: Dyck PJ, Thomas PK, Griffin JW, Low PA, Poduslo JF (eds), Peripheral Neuropathy, W.B.Saunders Co, Philadelphia pp 1219-1250

13. Mizisin AP, Calcutt NA, Tomlinson DR, Gallagher A, Fernyhough P (1999) Neurotrophin-3 reverses nerve conduction velocity deficits in streptozotocin-diabetic rats. J Periph Nerv Sys 4: 211-221

14. Tomlinson DR, Fernyhough P, Diemel LT (1996) Neurotrophins and peripheral neuropathy. Philos Trans R Soc Lond B Biol Sci 351: 455-462

15. Mohiuddin L, Fernandez K, Tomlinson DR, Fernyhough P (1995) Nerve growth factor and neurotrophin-3 enhance neurite outgrowth and up-regulate the levels of messenger RNA for growth-associated protein GAP-43 and T $\alpha 1 \beta$-tubulin in cultured adult rat sensory neurones. Neurosci Lett 185: $20-23$
16. Usachev Y, Shmigol A, Pronchuk N, Kostyuk P, Verkhratsky A (1993) Caffeine-induced calcium release from internal stores in cultured rat sensory neurons. Neuroscience 57: $845-859$

17. Wrathchall JR, Rigamonti DD, Bradford MR, Kao CC (1981) Non-neuronal cell cultures from doersal root gamglia of the adult rat: production of Schwann-like cell lines. Brain Res 229: 163-181

18. England S, Heblich F, James IF, Robbins J, Docherty RJ (2001) Bradykinin evokes a $\mathrm{Ca}^{2+}$-activated chloride current in non-neuronal cells isolated from neonatal rat dorsal root ganglia. J Physiol 530: 395-403

19. Kirischuk S, Verkhratsky A (1996) $\left[\mathrm{Ca}^{2+}\right]_{\mathrm{i}}$ recordings from neural cells in acutely isolated cerebellar slices employing differential loading of the membrane-permeant form of the calcium indicator fura-2. Pflugers Arch 431: 977-983

20. Shmigol A, Kostyuk P, Verkhratsky A (1994) Role of caffeine-sensitive $\mathrm{Ca}^{2+}$ stores in $\mathrm{Ca}^{2+}$ signal termination in adult mouse DRG neurones. Neuroreport 5: 2073-2076

21. Verkhratsky A, Shmigol A (1996) Calcium-induced calcium release in neurones. Cell Calcium 19: 1-14

22. Verkhratsky A, Petersen OH (1998) Neuronal calcium stores. Cell Calcium 24: 333-343

23. Sitsapesan R, Williams AJ (1990) Mechanisms of cafeine activation of single calcium-release channels of sheep cardiac sarcoplasmic reticulum. J Physiol (Lond) 423: 425-439

24. Ralevic V, Burnstock G (1998) Receptors for purines and pyrimidines. Pharmacol Rev 50: 413-492

25. Svichar N, Shmigol A, Verkhratsky A, Kostyuk P (1997) ATP induces $\mathrm{Ca}^{2+}$ release from $\mathrm{InsP}_{3}$-sensitive $\mathrm{Ca}^{2+}$ stores exclusively in large DRG neurones. Neuroreport 8: 1555-1559

26. Grubb BD, Evans RJ (1999) Characterization of cultured dorsal root ganglion neuron $\mathrm{P} 2 \mathrm{X}$ receptors. Eur J Neurosci 11: $149-154$

27. Lalo U, Voitenko N, Kostyuk P (1998) Iono- and metabotropically induced purinergic calcium signalling in rat neocortical neurons. Brain Res, 799: 285-291

28. Svichar N, Shmigol A, Verkhratsky A, Kostyuk P (1997) $\mathrm{InsP}_{3}$-induced $\mathrm{Ca}^{2+}$ release in dorsal root ganglion neurones. Neurosci Lett 227: 107-110

29. Malcangio M, Tomlinson DR (1998) A pharmacologic analysis of mechanical hyperalgesia in streptozotocin/diabetic rats. Pain 76: 151-157

30. Calcutt NA, Jorge MC, Yaksh TL, Chaplan SR (1996) Tactile allodynia and formalin hyperalgesia in streptozotocindiabetic rats: effects of insulin, aldose reductase inhibition and lidocaine. Pain 68: 293-299

31. Fernyhough P, Diemel LT, Hardy J, Brewster WJ, Mohiuddin L, Tomlinson DR (1995) Human recombinant nerve growth factor replaces deficient neurotrophic support in the diabetic rat. Eur J Neurosci 7: 1107-1110

32. Apfel SC, Arezzo JC, Brownlee M, Federoff H, Kessler JA (1994) Nerve growth factor administration protects against experimental diabetic sensory neuropathy. Brain Res 634: $7-12$

33. Diemel LT, Brewster WJ, Fernyhough P, Tomlinson, DR (1994) Expression of neuropeptides in experimental diabetes; effects of treatment with nerve growth factor or brainderived neurotrophic factor Brain Res Mol Brain Res 21: 171-175

34. Fernyhough P, Diemel LT, Tomlinson DR (1998) Target tissue production and axonal transport of neurotrophin-3 are reduced in streptozotocin-diabetic rats. Diabetologia 41: 300-306

35. Akkina SK, Patterson CL, Wright DE (2001) GDNF rescues nonpeptidergic unmyelinated primary afferents in 
streptozotocin-treated diabetic mice. Exp Neurol 167: 173-182

36. Ramer MS, Bradbury EJ, McMahon SB (2001) Nerve growth factor induces $\mathrm{P} 2 \mathrm{X}(3)$ expression in sensory neurons. J Neurochem 77: 864-875

37. Michael GJ, Averill S, Shortland PJ, Yan Q, Priestley JV (1999) Axotomy results in major changes in BDNF expression by dorsal root ganglion cells: BDNF expression in large trkB and trkC cells, in pericellular baskets and in projections to deep dorsal horn and dorsal column nuclei. Eur J Neurosci 11: 3539-3551

38. Dechant G, Tsoulfas P, Parada LF, Barde YA (1997) The neurotrophin receptor $\mathrm{p} 75$ binds neurotrophin-3 on sympathetic neurons with high affinity and specificity. J Neurosci 17: 5281-5287

39. Belliveau DJ, Krivko I, Kohn J et al. (1997) NGF and neurotrophin-3 both activate TrkA on sympathetic neurons but differentially regulate survival and neuritogenesis. J Cell Biol 136: 375-388

40. Farinas I, Wilkinson GA, Backus C, Reichardt LF, Patapoutian A (1998) Characterization of neurotrophin and
Trk receptor functions in developing sensory ganglia: direct NT-3 activation of TrkB neurons in vivo. Neuron 21: 325-334

41. Yuen EC, Mobley WC (1999) Early BDNF, NT-3, and NT-4 signaling events. Exp Neurol 159: 297-308

42. Clary DO, Reichardt LF (1994) An alternatively spliced form of the nerve growth factor receptor TrkA confers an enhanced response to neurotrophin 3. Proc Natl Acad Sci USA 91: 11133-11137

43. Gavazzi I, Kumar RD, McMahon SB, Cohen J (1999) Growth responses of different subpopulations of adult sensory neurons to neurotrophic factors in vitro. Eur J Neurosci 11: 3405-3414

44. Friel DD (2000) Mitochondria as regulators of stimulusevoked calcium signals in neurons. Cell Calcium 28: 307-316

45. Fernyhough P, Diemel LT, Brewster WJ, Tomlinson DR (1995) Altered neurotrophin mRNA levels in peripheral nerve and skeletal muscle of experimentally diabetic rats. J Neurochem 64: 1231-1237 